\title{
Improving the System of Budgeting at Industrial Enterprises
}

\author{
Larisa Yuzvovich*, Ekaterina Korogodina, and Lucia Azisova \\ Ural Federal University, Ekaterinburg, Russia
}

\begin{abstract}
The scientific article is devoted to the issues of budgeting system at industrial enterprises. The problem of improving the budgeting system in the enterprises of the corporate sector has always been a key issue for both government and business. In a time of economic turmoil and post-crisis periods, this problem becomes even more relevant. Methodological tools are analytical and economic methods of information processing. The relevance, theoretical and practical significance of the scientific research is determined by the focus on solving an important scientific and practical problem of empirical importance for budgeting within the financial planning system with limited financial resources and optimization of project financing sources.
\end{abstract}

\section{Introduction}

\subsection{Statement of the Problem}

Current economic environment makes Russian enterprises search for more efficient methods to control operational and financial performance, involving all available tools of financial management, one example of which is budgeting. It is crucial for manufacturing business where portfolio diversification and effective production are vital tasks of financial and operational activities within the framework of strategic development for every business as well as region's economy.

\subsection{Importance of the Problem}

The system of budgeting, being one of the ways of managing financial operations, significantly increases the efficiency of cash management of a company, preventing misallocation of finances, whether at a planning stage, or as part of audit.

Business management of a company is done by creating and developing the system of money relations as a foundation and prerequisite for generating and using financial resources and business capital, i.e. business finance.

Financial resources, as part of tangible assets, at a microlevel of economy represent an accounting entity which is analysed, planned, allocated and used to achieve the goals of the financial plan (budget) of an enterprise. Since a company is an open economic and social system, in order to support and develop its business activity it is required to coordinate business internal capacity with needs and changes of external environment.

To enhance budgeting efficiency it is viable to classify revenue and expenditure in terms of functions as well as resources, as in this case economic data is collected and analysed both as running business processes and types of resources in the income-expenses accounting. The implementation of this methodology improves the quality of analysis and agility of budgeting.

\subsection{Practical Application}

The practical contribution of this research implies that the developed improvements of budgeting system are accepted as guidelines by the management of PAO Uralskiy zavod RTI (a publicly held manufacturing plant of industrial rubber products in the Ural region), within the new framework of setting strategic goals and tactical planning, developing draft budgets (cost and profit estimates) of future operations and budget performance monitoring. Practical implications of enhancing the budgeting system represent an efficient method of financial planning as it includes an exhaustive description of company economic indicators.

PAO Uralskiy zavod RTI sees its major task of budgeting in increasing the performance efficiency of the enterprise via goal orientation and coordination of all events, including changes of economic assets and its sources, risk detection and mitigation, as well as raising flexibility of business unit performance.

\subsection{Stating Hypothesis and Research Design}

Modern trends in management state that the budgeting system ought to be based on in-depth market study, awareness of customers and contractors, involvement of several managers and specialists with different levels of responsibility in the process of budgeting and running a company in order to reach the desired financial performance.

The current system of budgeting is one of the essential management mechanism in business. The overarching goal of budgeting is promoting the transparency of business activities. Thus budgeting becomes an effective tool for company directors in management and supervision [13].

Nikulina N.N. (the candidate of economic science, PhD) interprets budgeting as the process of organizing, planning, 
analyzing and monitoring the financial operations. Planning plays an outstanding role in budgeting as it includes the development of quality and quantity objectives as well as the selection of efficient ways to achieve them [9].

Kovalenko L.P. (the economist) claims that budgeting is the process of planning future activities of a company and describing the performance results as a system of interrelated budgets which have such special features as orientation to market demands as well as clarity and consistency in costbenefit approach, i.e. clear costing and regular cost-benefit analysis [6].

In terms of legislation, budgeting is regarded as an element of financial planning [1]

The dictionary of financial and legal terms defines budgeting as planning the financial performance on the basis of established budgets, the analysis and control of budget implementation [7].

When developing the sequential and logic system of budgeting the whole manufacturing process is broken down into certain stages of production. Every stage can represent a complete cycle [8].

The main purpose of a budgeting system lies in increasing the economic efficiency and financial sustainability of business, as well as maximum soundness of financial decisions.

Implementation of budgeting systems in business enables: to make feasible forecasts of business and financial performance;

- to detect in time bottlenecks in running a company;

to estimate the economic impact in case of possible deviations from a plan with the help of financial models and take an effective managerial decision;

to harmonize the work of company departments and units to reach the target objectives;

to improve business manageability by immediate detection of deviations from planned indicators.

The system of budgeting represents a technology of financial planning, accounting and control of business income and expenditure at every level of management, which enables the analysis of the anticipated and obtained financial results [4].

The relevance of the budgeting system is evident due to:

- an ever rising level of competition among companies, leading to the necessity to gain an edge in the competition (via more efficient financial management);

- the necessity for every business to search for internal reserves in order to reduce costs on production and sale, to justify the optimum levels of finance expenditure;

- the arising need in better investment prospects, as investors are more likely to be attracted to companies with higher level of management.

The budgeting entities can be production, sale and other activities, classified in terms of location, technology (units) or market niche [14].

On a free market the budgeting system provides the production of rival products via targeted search, evaluation and selection of alternatives to guarantee optimum employment of resources, therefore, budgeting with sound financial management is aimed at flexible business development.

Nowadays the goal of budgeting is to increase the efficiency of business performance which means:
- goal orientation and coordination of all activities in a company;

- risk detection and mitigation;

- improving flexibility and industrial mobility [11].

In economic terms, budgeting allows to ensure capital sufficiency for production, investment and financial operations.

A well-developed system of budgeting is crucial for an enterprise, especially large one. It can help to better coordinate the work of all departments, avoid crisis, improve motivation, increase reliability of managers at every level, predict financial results, prevent undesirable outcome.

Improving budgeting in manufacturing industries is a strategic task of every business owner. This is especially true for the enterprises that can run their own R\&D (research and development) projects in order to improve their business performance and financial sustainability as well as maximum soundness of financial decisions.

\section{Method}

\subsection{Method of Statistical Monitoring}

The publicly held Ural manufacturing plant of industrial rubber products (from now on - PAO Uralskiy zavod RTI) has run its business in chemical industry since 1941, and now is one of the leading Russian enterprises, producing industrial rubber products.

The strategic mission of the company is to dominate the Russian market of industrial rubber products in key industries by means of maximum satisfaction of customers' demands. The business objectives are to satisfy the customer demand in industrial rubber products and to develop before- and aftersales service. To reach this aim the business priorities are established (see Table 1) that take into account current market trends.

Table 1 shows that the company focuses on improving competitiveness, retaining the existing customers and attracting new ones. The business priorities of the enterprise in terms of raising competitiveness are:

_ innovating technologies, upgrading the production technology;

- enhancing production process;

- improving procurement quality;

- efficient use of fuel and energy resources;

- better quality management;

- product differentiation.

PAO Uralskiy zavod RTI caters not only for the main regions in Russia, but also for the CIS countries. The main export share belongs to Kazakhstan (74\%), Belarus (9\%).

Cooperation with these foreign partners is the main international business priority of the company, because these countries have high concentration of mining and machinebuilding enterprises which consume great amounts of industrial rubber products [15].

Table 1. Business priorities of PAO Uralskiy zavod RTI [15].

\begin{tabular}{|l|l|l} 
№ & Activity area & Characteristics
\end{tabular}




\begin{tabular}{|c|l|l|}
\hline 1 & $\begin{array}{l}\text { Increasing the } \\
\text { share of customers } \\
\text { from the upcoming } \\
\text { industrial sectors } \\
\text { (mining, ferrous } \\
\text { and non-ferrous } \\
\text { metal industry, } \\
\text { machine-building) }\end{array}$ & $\begin{array}{l}\text { - Increase in production and } \\
\text { sales by means of attracting } \\
\text { direct consumers from the } \\
\text { upcoming sectors; } \\
\text { - Improving competitiveness } \\
\text { by enhancing the quality of } \\
\text { manufactured goods, } \\
\text { developing new salable } \\
\text { products, experimenting } \\
\text { with new types of raw } \\
\text { produce, materials and } \\
\text { innovative technologies }\end{array}$ \\
\hline 2 & $\begin{array}{l}\text { Attracting new } \\
\text { customers from } \\
\text { peripheral sectors } \\
\text { (energy, oil and } \\
\text { gas) }\end{array}$ & $\begin{array}{l}\text { The main reason: lower } \\
\text { customer demand in the } \\
\text { major industries-consumers } \\
\text { of industrial rubber products }\end{array}$ \\
\hline 3 & $\begin{array}{l}\text { Focusing on } \\
\text { promising products }\end{array}$ & $\begin{array}{l}\text { Expansion of production, } \\
\text { quality requirement } \\
\text { toughening, introduction of } \\
\text { more competitive prices to } \\
\text { promote products at the } \\
\text { markets of Russia and CIS }\end{array}$ \\
\hline 4 & $\begin{array}{l}\text { Capacity extension } \\
\text { via purchasing new } \\
\text { equipment and } \\
\text { upgrading the } \\
\text { existing one }\end{array}$ & $\begin{array}{l}\text { In 2015 the programme of } \\
\text { technical upgrading and } \\
\text { retooling continued. The } \\
\text { most notable ongoing } \\
\text { investment project is the } \\
\text { upgrading of rubber } \\
\text { production }\end{array}$ \\
\hline
\end{tabular}

\subsection{Method of Analysis and Measurement}

The operating budget represents the estimate of financial needs for future business, including the planned sales and production. The operating budget is aimed at managing the current operational activities, to monitor its promptness. It is related with planning the volume and range of products, developing the manufacturing programme of company divisions, based on the available capacity. Also, the operating budget reflects supply and sale activities. Besides, the budget contains all the data concerning the company expenditure. The operating budget presents the total of income and expenses estimates. This data is given in Table 2.

The analysis of the table 2 shows the growing profit from the operational activities by $39 \%$ in 2017 compared with 2016. This is due to harmonizing the relations with suppliers and customers, as in 2016 the economy sanctions, imposed in 2015 , continued, while the exchange rate of ruble was volatile which affected the company, since most orders are in foreign currency. Thus, the operating budget informs about the financial performance of the enterprise in the future (anticipated profit and expenditure). The budget is made on the basis of in-depth study of major parameters which underlie commercial activities of a company (suppliers and customers), after that production and sales targets are defined. The final stage involves budgeting of expenditure. All of the above mentioned data forms the operating budget.

Table 2. Operating budget, RUB, in thousands [3].

\begin{tabular}{|l|c|c|}
\hline \multicolumn{1}{|c|}{ Indices } & 2016 & 2017 \\
\hline $\begin{array}{l}\text { Revenue from } \\
\text { proceeding of sales, } \\
\text { goods and service }\end{array}$ & 1625752.9 & 1387159 \\
\hline Direct expenses & 1051263.2 & 763706 \\
\hline Marginal income & 574489.7 & 623453 \\
\hline Fixed factory overhead & 344381.2 & 356477 \\
\hline Gross profit (loss) & 230108.5 & 266976 \\
\hline $\begin{array}{l}\text { Administrative } \\
\text { expenses }\end{array}$ & 196381 & 156719 \\
\hline Selling expenses & 28442.9 & 30511.9 \\
\hline Sales profit (loss) & 5284.6 & 79744.9 \\
\hline $\begin{array}{l}\text { Other operating income } \\
\text { and expenses }\end{array}$ & 95114.1 & -24537 \\
\hline $\begin{array}{l}\text { Non-operating gains } \\
\text { and losses }\end{array}$ & -19667.3 & 47748.5 \\
\hline Before-tax profit (loss) & 80731.4 & 102957 \\
\hline Net profit (loss) & 57793.8 & 80541.8 \\
\hline
\end{tabular}

The financial budget includes the calculated financial resources and suggestions of their use. The aim of the financial budget is planning the balance of revenue from financial investment activities and expenditure from those activities so that the enterprise can keep its financial sustainability within the budgeting period. The financial budget is aimed at planning and managing cash flows. It describes incoming and outgoing cash flows in cash and noncash settlements within the budgeting period. The financial budget contains: investment budget; cash flow budget.

All the data concerning the financial and investment activities results in the financial budget, given in Table 3 .

It can be concluded from Table 3 that in 2016 and 2017 the financial and investment operations of the company yielded losses. That was caused by reduction in investments, as the main investment activity in 2016 and 2017 was purchase/sale of fixed capital and intangible assets. The data of the operating and financial budgets serve as a basis for the cash flow budget.

All the above mentioned data, including operational, investment and financial activities, finally result in the cash flow budget.

The cash flow budget reflects the need in external financing (volume of credit, investment), as well as enables a more precise calculation of external financing volume. The aim of the budget is to guarantee cash inflow (estimated income) and writing off (estimated expenditure of budgeting periods) $[4,12]$.

Developing the cash flow budget means defining the potential sources of cash in the coming budget period. The budget is presented in Table 4 .

Table 3. Financial budget, RUB, in thousands [2].

\begin{tabular}{|c|c|c|}
\hline Budget item & 2016 & 2017 \\
\hline
\end{tabular}




\begin{tabular}{|l|c|c|}
$\begin{array}{l}\text { Income from } \\
\text { investments }\end{array}$ & 230592.40 & 35000.00 \\
\hline $\begin{array}{l}\text { Investment } \\
\text { payments }\end{array}$ & 108378.20 & 90839.10 \\
\hline $\begin{array}{l}\text { Investment cash } \\
\text { flow }\end{array}$ & 122214.20 & -55839.10 \\
\hline $\begin{array}{l}\text { Income from } \\
\text { financial activities }\end{array}$ & 648364.30 & 293724.50 \\
\hline $\begin{array}{l}\text { Financial } \\
\text { activities } \\
\text { payments }\end{array}$ & 934240.50 & 304724.50 \\
\hline $\begin{array}{l}\text { Cash flow from } \\
\text { financial activities }\end{array}$ & -285876.20 & -11000.00 \\
\hline $\begin{array}{l}\text { Net cash flow } \\
\text { total) }\end{array}$ & -163662.00 & -66839.10 \\
\hline
\end{tabular}

Table 4. Cash flow budget, RUB, in thousands [2].

\begin{tabular}{|l|c|c|}
\hline \multicolumn{1}{|c|}{ Budget item } & 2016 & 2017 \\
\hline $\begin{array}{l}\text { Income from } \\
\text { investments }\end{array}$ & 230592.40 & 35000.00 \\
\hline $\begin{array}{l}\text { Investment } \\
\text { payments }\end{array}$ & 108378.20 & 90839.10 \\
\hline $\begin{array}{l}\text { Investment cash } \\
\text { flow }\end{array}$ & 122214.20 & -55839.10 \\
\hline $\begin{array}{l}\text { Income from } \\
\text { financial activities }\end{array}$ & 648364.30 & 293724.50 \\
\hline $\begin{array}{l}\text { Financial } \\
\text { activities } \\
\text { payments }\end{array}$ & 934240.50 & 304724.50 \\
\hline $\begin{array}{l}\text { Cash flow from } \\
\text { financial activities }\end{array}$ & -285876.20 & -11000.00 \\
\hline $\begin{array}{l}\text { Net cash flow } \\
\text { from operating } \\
\text { activities }\end{array}$ & 57793.80 & 80541.80 \\
\hline $\begin{array}{l}\text { Net cash flow } \\
\text { total) }\end{array}$ & -105868.20 & 13702.70 \\
\hline
\end{tabular}

According to Table 4, in 2017 the company gained profit. This was due to the fact that the company managed to adapt to unfavourable economy and reach the established development targets such as:

- improving the customer base;

- upgrading the equipment;

- enhancing the quality of products.

The main causes of losses in 2016 are:

1) changeable macroeconomic environment both in the industry and the country;

2) loss of major customers;

3) erosion of previous delivery agreements in foreign currency due to the plummeting exchange rate of ruble.

Therefore, the financial budget consists of investment and financial indices. Investment indicators include fixed capital investments and intangible assets, while financial ones contain long-term and short-term credits.

\subsection{Method of Observational Generalization and Logical Inference}

Budgeting as a management tool is aimed at organizing the system of analysis and planning of financial resources, based on development and control of executing the hierarchical sequence of creating company budgets which enables to establish comprehensive running and effective control over incoming and outgoing cash flows, as well as to make realistic conditions for building an efficient financial strategy.

Budgeting is based on the principles of integrated planning, accounting, control, analysis and regulation of company performance, financial results and financial reliability of every business unit; coordination of the corresponding business budgets, its fiscal consolidation and orientation towards reaching the common financial objectives at every level of management.

\section{Results}

The central factory laboratory of the Institute of Rubber and Industrial Rubber Products is the leading science and research institution in Russian regions. The main activities include:

- development of new products;

- guarantee testing;

- science and technology consultancy.

Implementation of R\&D budget enables:

- to structure income and expenditure in terms of strategic business;

- to control cash inflows and outflows;

- to analyse the soundness of expenses on business priorities.

The business priorities of PAO Uralskiy zavod RTI are:

- expansion of production capacity;

- $\quad$ focusing on promising products;

- attracting new customers.

As a basis for drafting the R\&D budget, it was decided to use the activities of the Institute of Rubber and Industrial Rubber Products from 2016 to 2017 as well as the plan estimates for 2018. The budget is given in Table 5 .

The Table 5 shows that the performance of the Institute of Rubber and Industrial Rubber Products is likely to profit. The profit analysis of 2016 and 2017 suggests that in 2018 reduction in income is anticipated. The main reasons include:

- reduction of sale proceeds by $4.2 \%$. As the activities of the Institute of Rubber and Industrial Rubber Products focus on selling the results of research and development work, there is an issue with search for customers;

- increase of direct expenses by $20 \%$. It is caused by growing salary of the management;

- $\quad$ rising selling expenses by $7 \%$. These costs arise as a result of products promotion.

Table 5. R\&D draft budget for 2018, RUB, in thousands [3].

\begin{tabular}{|l|c|c|c|}
\hline \multicolumn{1}{|c|}{ Budget item } & $\begin{array}{c}2016, \\
\text { actually }\end{array}$ & $\begin{array}{c}2017, \\
\text { actually }\end{array}$ & $\begin{array}{c}2018, \\
\text { planned }\end{array}$ \\
\hline $\begin{array}{l}\text { Product } \\
\text { proceeding }\end{array}$ & 50796.20 & 47082.50 & 45199.20 \\
\hline Direct expenses & 15578.90 & 14709.50 & 14268.20 \\
\hline
\end{tabular}




\begin{tabular}{|l|c|c|c|}
$\begin{array}{l}\text { Marginal } \\
\text { income }\end{array}$ & 35217.30 & 32373.00 & 30931.00 \\
\hline Constant costs & 16791.20 & 10834.50 & 13001.40 \\
\hline $\begin{array}{l}\text { Gross profit } \\
\text { (loss) }\end{array}$ & 18426.10 & 21538.50 & 17929.60 \\
\hline Selling expenses & 4740.50 & 5085.30 & 5441.30 \\
\hline $\begin{array}{l}\text { Sales profit } \\
\text { (loss) }\end{array}$ & 13685.60 & 16453.20 & 12488.30 \\
\hline
\end{tabular}

The R\&D budget represents a complex structure, since it is long term oriented. This is an expensive method, budgeting implies having a high level of expertise which includes: experience and qualifications of designated staff, modern technologies, access to quality information concerning strategic units.

\section{Discussion}

Efficient budgeting of R\&D enables business to optimize costs, as expenses on development represent the essential part of company strategy for success in the future.

The purchasing directors provided the detailed description of activities, leading to the reduction of expenditure and increasing income, together with statistical data. Such approach is very illustrative, as it shows the final achievements of the planned operations which can be seen in Table 6.

The analysis of the above mentioned data enables to conclude that the company management and the managerial board highlight a few major activities in 2018 which optimize expenditure and increase income:

- growing sales by means of analysis and renewal of customer base by $15 \%$;

- decreasing expenses, related with transportation, three-fold reduction due to replacing motor vehicles with railway delivery;

import substitution of raw materials and supplies, search for domestic equivalents;

- effective planning: order consolidation in terms of industries, staff rightsizing in industries.

It is suggested that the implementation of $R \& D$ budget will enable to increase investment opportunities, as the Institute of Rubber and Industrial Rubber Products is responsible for improving the quality of products, upgrading the equipment, overall, its activities are aimed at raising the company competitiveness.

Consequently, the R\&D budget guarantees control over investment cash inflows and outflows from the top executive management.

The budgeting system of PAO Uralskiy zavod RTI is a detailed description of main economic indicatots that enables to detect major problems and to solve them by means of devising budgets of optimization operations.

Table 6. Procurement policy of material supply for 2018 [10].

\begin{tabular}{|c|c|c|}
\hline $\begin{array}{c}\text { № } \\
\text { of } \\
\text { item }\end{array}$ & $\begin{array}{c}\text { Optimization } \\
\text { area of } \\
\text { expenses/income } \\
\text { growth }\end{array}$ & Actions expected \\
\hline
\end{tabular}

\begin{tabular}{|c|c|c|}
\hline 1 & $\begin{array}{l}\text { Import } \\
\text { substitution of } \\
\text { raw materials } \\
\text { and supplies }\end{array}$ & $\begin{array}{l}\text { Material cost of antimony } \\
\text { trioxide (China) OOO } \\
\text { Ruskhimset } 1 \text { ton } 670 \text { thousand } \\
\text { RUB x } 11 \text { tons (annual demand) } \\
=7370000,0 \text { RUB } \\
\text { Material cost OOO NPT } \\
\text { Elektrum Novosibirsk } 1 \text { ton } 550 \\
\text { thousand RUB x } 11 \text { tons } \\
\text { (annual demand) }=6050000.0 \\
\text { RUB }\end{array}$ \\
\hline 2 & $\begin{array}{l}\text { Getting rid of } \\
\text { dead stock }\end{array}$ & $\begin{array}{l}\text { Placement on the factory site } \\
\text { and sales areas. Internet } \\
\text { information about getting rid of } \\
\text { surplus stock and materials }\end{array}$ \\
\hline 3 & $\begin{array}{l}\text { Reforming the } \\
\text { purchase of } \\
\text { components for } \\
\text { packaging, } \\
\text { reducing } \\
\text { expenses on } \\
\text { purchasing } \\
\text { lumber }\end{array}$ & $\begin{array}{l}\text { The annual reduction in } \\
\text { expenses is } 30 \%\end{array}$ \\
\hline 4 & $\begin{array}{l}\text { Reforming the } \\
\text { delivery of } \\
\text { reclaim from } \\
\text { Volzhsky, } \\
\text { replacing motor } \\
\text { vehicles with } \\
\text { railway }\end{array}$ & $\begin{array}{l}\text { With the quarterly need in } \\
\text { reclaim on average equal to } 60 \\
\text { tons, the delivery costs by car } \\
\text { are } 450 \text { - } 500 \text { thousand RUB, } \\
\text { railway costs are } 145-155 \\
\text { thousand RUB. }\end{array}$ \\
\hline 5 & $\begin{array}{l}\text { Quarterly } \\
\text { delivery }\end{array}$ & $\begin{array}{l}\text { With the quarterly need in } \\
\text { acetone anil equal to } 6 \text { tons, } 3 \\
\text { deliveries cost } 90 \text { thousand } \\
\text { RUB, in case there is just one } \\
\text { quarterly delivery, the expenses } \\
\text { are down to } 50 \text { thousand RUB }\end{array}$ \\
\hline 6 & $\begin{array}{l}\text { Merging the } \\
\text { finished } \\
\text { products storage } \\
\text { areas }\end{array}$ & $\begin{array}{l}\text { Redistribution of duties among } \\
\text { store keepers, make two } \\
\text { positions of store keepers } \\
\text { redundant }\end{array}$ \\
\hline 7 & $\begin{array}{l}\text { Reduction of } \\
\text { storage area }\end{array}$ & Renting out free storage area \\
\hline
\end{tabular}

The company has major units, responsible for making and executing budgets, every unit creates a concrete budget which reduces risks, related with errors and invalid economic data and wrong statistics.

The authors are sincerely grateful to Degtyarev Sergey Anatolyevitch, the chief accountant of Uralskaya gornometallurgitcheskaya kompaniya (Ural mining and concentrating company), Yekaterinburg, Russia, for active participation in preparing the materials concerning the improvements in the budgeting system in industrial enterprises with their own research and development centres.

\section{References}

1. The Order of the Russian Ministry of Economy «The establishment of Methodological recommendations on reforming enterprises (organizations)» from 01.10.1997 № 118. Economy and life 49-52 (1997); 2 (1998) 
2. Cash flow budget (PAO Uralskiy zavod RTI., Yekaterinburg)

3. Revenue and expenditure budget (PAO Uralskiy zavod RTI., Yekaterinburg)

4. S. V. Bulgakova, Management accounting: coursebook (Voronezh: Publishing house of Voronezh State University, 2015)

5. V. L. Nazarova, M. V. Shtiller, I. V. Selezneva, O. Yu. Kohut, G. Zh. Seytkhamzina, Indian Journal of Science and Technology 9(5), (2016)

6. L. P. Kovalenko, The role of budgeting in management (Moscow: Laboratoriya Knigi, 2012)

7. KonsultantPlus [Electronic source]. Available at: http://www.consultant.ru (date of access 20.03.2017).

8. E. L. Maslova, Management: coursebook (Moscow: Publishing corporation Dashkov and Co, 2016)

9. N. N. Nikulina, D. V. Sukhoedov, N. D. Eriashvili, Financial management of organisations. Theory and practice: university coursebook (Moscow: YUNITIDANA, 2012)

10. The main directions of budget optimization (PAO Uralskiy zavod RTI., Yekaterinburg)

11. L. V. Strelkova, Y. A. Makusheva, Management planning: workbook (Moscow: YUNITI-DANA, 2015)

12. A.G. Tashkinov, Strategy-based budgeting at the industrial enterprise: methodological approach (Perm University Herald, 2013)

13. E. B. Tyutyukina, Corporate Finance (business finance): coursebook (Moscow: Publishing corporation Dashkov and Co, 2016)

14. Y. A. Khegay, Z. A. Vasilyeva, Cost Management: workbook (Krasnoyarsk : Siberian Federal University, 2015)

15. Uralskiy plant of industrial rubber products [Electronic source]. Available at: http://www.uralrti.ru (date of access 12.03.2017) 